\title{
The revised taxonomic placement of the genus Acentropelma Pocock, 1901 and restoration of the genus Pseudoschizopelma Smith, 1995
} (Aranei: Theraphosidae)

\author{
Пересмотр таксономического положения рода Acentropelma \\ Pocock, 1901 и восстановление рода Pseudoschizopelma Smith, 1995 \\ (Aranei: Theraphosidae)
}

\author{
Ray Gabriel, Danniella Sherwood*, Stuart J. Longhorn

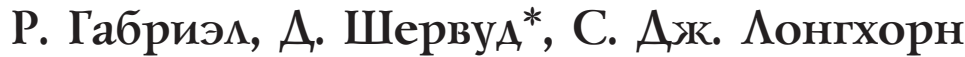

Arachnology Research Association, United Kingdom.

* Corresponding author: danni.sherwood@hotmail.com

KEY WORDS: Araneae, taxonomy, morphology, Mexico, Belize, Guatemala, tarantula.

КЛЮЧЕВЫЕ СЛОВА: Araneae, таксономия, морфология, Мексика, Белиз, Гватемала, птицееды.

ABSTRACT. The genus Acentropelma Pocock, 1901 is redefined and the type species, $A$. spinulosum F.O. Pickard-Cambridge, 1897 is redescribed. Pseudoschizopelma Smith, 1995 gen.rest. is restored to house Acentropelma macropus (Ausserer, 1875) creating the restored combination Pseudoschizopelma macropus comb.rest. Acentropelma sorkini Smith, 1995 syn.n. is considered a junior synonym of $P$. macropus based on indistinguishable palpal bulb, tibial apophysis and spermathecal morphology. The paratype female of former A. sorkini, originally designated and described by Smith [1995] is found to be an immature Brachypelma Simon, 1891 - possibly Brachypelma kahlenbergi Rudloff, 2008. Additional morphological features for $A$. gutzkei are included to complement the original description by Reichling [1997], and its placement discussed.

How to cite this article: Gabriel R., Sherwood D., Longhorn S.J. 2020. The revised taxonomic placement of the genus Acentropelma Pocock, 1901 and restoration of the genus Pseudoschizopelma Smith, 1995 (Aranei: Theraphosidae) // Arthropoda Selecta. Vol.29. No.4. P.453-466. doi: 10.15298/arthsel. 29.4.07

РЕЗЮМЕ. Состав рода Acentropelma Pocock, 1901 пересмотрен, а его типовой вид A. spinulosum F.O. Pickard-Cambridge, 1897 - переописан. Восстановлен род Pseudoschizopelma Smith, 1995 gen.rest. для Acentropelma macropus (Ausserer, 1875), с восстановлением оригинальной комбинации Pseudoschizopelma macropus comb.rest. Acentropelma sorkini Smith, 1995 syn.n. рассматривается в качестве младшего синонима P. macropus, основываясь на отсутствии различий в строении бульбуса пальпы, тибиального апофиза и морфологии сперматек. Выявлено, что описанная Смитом [Smith, 1995] самка, обозначенная им в качестве паратипа бывшего
A. sorkini, является неполовозрелым экземпляром одного из видов рода Brachypelma Simon, 1891 вероятно, B. kahlenbergi Rudloff, 2008. Дополнительные морфологические признаки для A. gutzkei включены в добавление к его первоначальному описанию [Reichling, 1997]; обсуждается таксономическая позиция последнего вида.

\section{Introduction}

The genus Acentropelma Pocock, 1901 was created by Pocock [1901] as monotypic within the family Theraphosidae Thorell, 1869 when the type species Acentropelma spinulosum (F.O. Pickard-Cambridge, 1897) from Guatemala was transferred from the genus Metriopelma Becker, 1878. Pocock [1901] defined Acentropelma from only male specimens based on "a scopula of relatively stout delicately plumose bristles" [Pocock, 1901: 551] on the anterior trochanter and femur of leg I and posterior trochanter of the palp, but disregarded the lack of male tibial apophyses that had previously been considered informative to place this species into Metriopelma. Simon [1903] regarded Acentropel$m a$ as a junior synonym of the genus Stichoplastus Simon, 1889, but did not specifically note the basis of this synonym, transferring A. spinulosum to Stichoplastus where it remained until Rudloff [1997] transferred it back to its earliest placement under Metriopelma based on the shared absence of male tibial apophyses.

During the period between the original description of the genus by Pocock [1901] to the most recent treatment by Gabriel [2016], species included in the now revised Acentropelma underwent many generic transfers. Ausserer [1875] described a male and female of a Mexican species as Crypsidromus macropus Ausserer, 1875, later F.O. Pickard-Cambridge [1897] 
transferred this species to Schizopelma F.O. PickardCambridge, 1897. Much later, Smith [1995] described Pseudoschizopelma Smith 1995 to house P. macropus along with a misattributed Guatemalan species $P$. pentaloris (formerly contained in Cyclosternum Ausserer, 1871 and later revised as Davus pentaloris by Gabriel [2016]), defining them together on several features but notably the twin spur of the male with 'primary segment' exceptionally long; as well as a ventrally keeled male embolus, and the single spermathecae of the female (see Smith 1995). This generic placement was not followed by Perez-Miles et al. [1996] (possibly due to the similar publication dates) who transferred $P$. macropus to Cyclosternum based on palpal bulb morphology and "other features of generic significance" [PerezMiles et al., 1996: 46]. Finally, Schmidt [2003, 2005] argued the species $P$. macropus instead belonged in the genus Davus O. Pickard-Cambridge, 1892, but this transfer was not followed by subsequent workers.

At the same time, Smith [1995] described Schizopelma sorkini Smith, 1995 from Mexico differentiating it from Schizopelma bicarinatum F.O. Pickard-Cambridge, 1897 by the reduced keels of the male embolus, 'heavy' spination of the palpal tibia and the narrower clypeus [Smith, 1995: 191]. He also provides several possible features to unite these two species within the same genus, perhaps most notably "Tibial spur — single spur capped with a long stout spine" which he also indicates as "key feature" [Smith, 1995: 189]. Smith also states for $S$. sorkini that: "It was collected from St. Andres, Mexico — which may be either Saint or San Andres. Unfortunately we have been unable to locate the original collection site, which in the 1880s was probably an isolated Catholic Mission. Likely to be in the Chiapas region" [Smith, 1995: 191], but gives no evidence to explain any of the latter aspects.

Two years later, Reichling [1997] described Crypsidromus gutzkei Reichling, 1997 based on a single male from Belize differentiating it from congeners based on several aspects he considered unique such as the bright red appearance (and lack of patterning) of the abdominal setae, its 'comparatively unmodified' male palpal embolus, plus noting other aspects like spination of the palpal tibia. The species was later implicitly placed under Lasiodora C.L. Koch, 1850 after the genus Crypsidromus was treated as a junior synonym, due to the transfer of $C$. isabellina Ausserer, 1871, by Pérez-Miles et al. [1996] who regarded $C$. isabellinus as a young specimen of an undetermined Lasiodora species (since it is indistinguishable from juvenile specimens of several Lasiodora species from the same region).

Gabriel [2016] restored the genus Acentropelma revalidating $A$. spinulosum, added $A$. macropus from Cyclosternum, A. sorkini Smith, 1995 from Schizopelma and A. gutzkei Reichling, 1997 from Lasiodora (= Crypsidromus) based on similar bulb morphology plus the presence of plumose setae found on the prolateral trochanter and femur of the first leg as well as on the retrolateral trochanter of the palp.
In this work, we revise the genus Acentropelma, provide detailed redescriptions of focal taxa and give discussion on the precedence of primary and secondary taxonomic features. Additionally we present comments on the systematic position of the intermediate and enigmatic A. gutzkei.

\section{Materials and methods}

Specimens were examined under a binocular microscope, photographs of spermathecae and palpal bulbs were made using Leica M125C auto-montage. Depositories: AMNH American Museum of Natural History, New York, United States of America; BMNH/NHMUK - Natural History Museum, London, United Kingdom; LAAHFC - Laboratorio de Acarología "Anita Hoffmann", Facultad de Ciencias, Universidad Nacional Autónoma de México, Mexico City, Mexico; NHMV - Natural History Museum, Vienna, Austria; OUMNH - Oxford University Museum of Natural History, United Kingdom; UNAM - Universidad Nacional Autonoma de Mexico, Mexico City, Mexico; ZMB - Museum fur Naturkunde, Berlin, Germany. Abbreviated structures: ALE - anterior lateral eyes, AME — anterior medial eyes, PLE - posterior lateral eyes, PME — posterior medial eyes. PB - prolateral branch (of tibial apophyses); RB retrolateral branch (of tibial apophyses). Leg spine terminology follows Petrunkevitch [1925] with the modifications proposed by Bertani [2001]: d - dorsal, v - ventral, r retrolateral, p - prolateral. Palpal bulb keel terminology follows Bertani [2000] with additions proposed by Gabriel [2016]: A — apical, DR — denticulate row, PI — prolateral inferior, PS - prolateral superior, RI - retrolateral inferior, RS - retrolateral superior, SA - subapical, TA tegular apophysis. Leg formulae starts with the longest leg to the shortest in order of decreasing size, e.g. 4,1,2,3. Terminology for stridulatory setae follows Galletti-Lima \& Guadanucci [2018, 2019]. All measurements are given in $\mathrm{mm}$. Authors' emphases are given as enclosed in square brackets $([\ldots])$.

\section{Results}

Family Theraphosidae Thorell, 1869

Subfamily Theraphosinae Thorell, 1869

Tribe Theraphosini Thorell, 1869

\section{Genus Acentropelma Pocock, 1901}

Acentropelma Pocock, 1901: 555; Gabriel, 2016: 84 (in part). Stichoplastus Simon, 1903: 930; Smith, 1986: 99, f. 108h; 1987: 99, f. 108h.

Cyclosternum: Pérez-Miles et al., 1996: 46 (in part).

Metriopelma: Rudloff, 1997: 2, 4 (in part).

TYPE SPECIES: Acentropelma spinulosum (F.O. Pickard-Cambridge, 1897) by original designation.

DIAGNOSIS. Acentropelma can be distinguished from other Theraphosinae genera largely by the combination of divergent aspects of the genital organs and the absence of tibial apophyses in the male. Acentropelma can be further differentiated from most other genera (except some such as Pseudoschizopema gen.rest.) by setal structures of anterior podomere bases with only plumose stridulatory setae (sensu Galletti-Lima \& Guadanucci, 2018, 2019) on the prolateral trochanter and proximal femur of leg I plus the retrolateral 

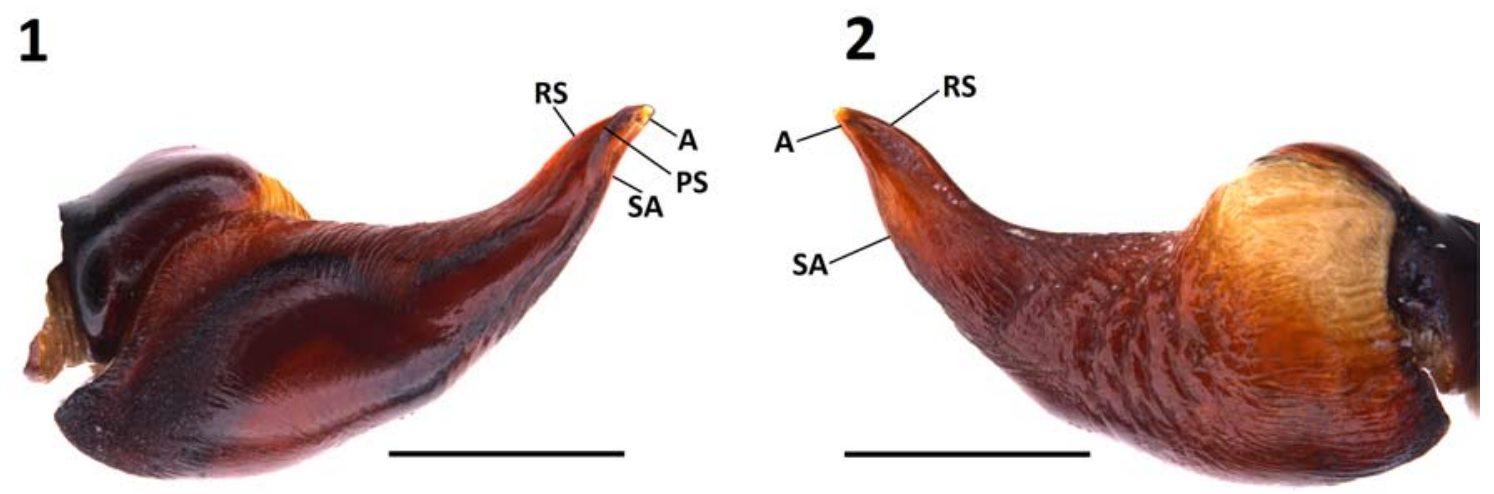

3
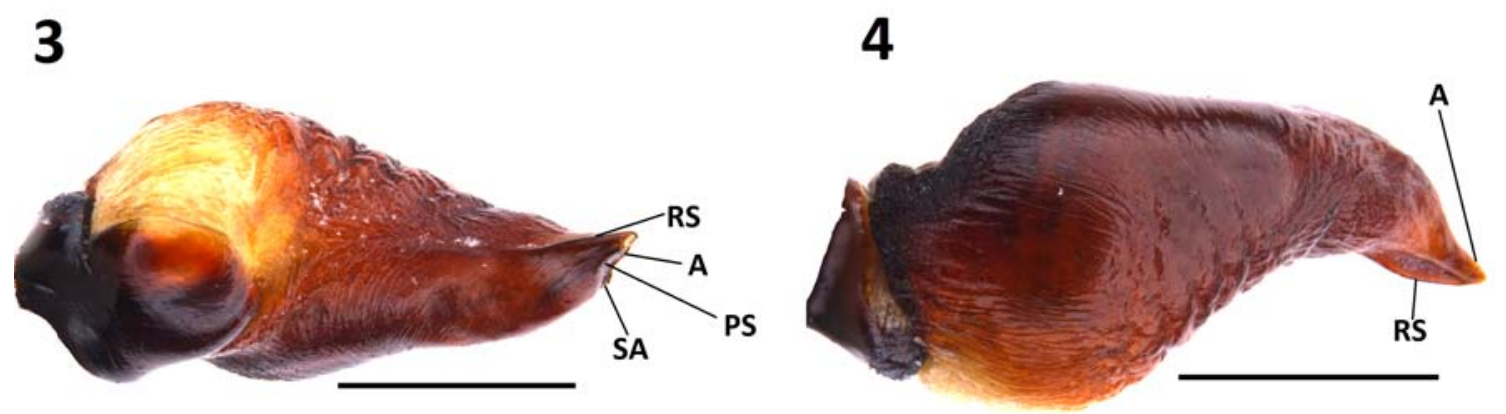

Figs. 1-4. Acentropelma spinulosum, holotype male (BMNH/NHMUK), palpal bulb (left hand side): 1 - prolateral view; 2 retrolateral; 3 - dorsal; 4 - ventral. Scale lines $=1 \mathrm{~mm}$.

Pис. 1-4: Acentropelma spinulosum, самец голотип (BMNH/NHMUK), бульбус пальпы (правая пальпа): 1 — пролатерально; 2 ретролатерально; 3 - сверху; 4 - снизу. Масштаб 1 мм.

palpal trochanter. We focus the diagnosis below to distinguish select genera that can be closely related due to similar morphology as well as being geographically close or indeed overlapping in distribution. These include: Citharacanthus Pocock, 1901, Pseudoschizopelma gen.rest., and Longilyra Gabriel, 2014, plus the historically confused genus Metriopelma, and others such as Lasiodora C.L. Koch 1850 sensu lato from Central America (which need taxonomic revision), and Neischnocolus Petrunkevitch, 1925. Acentropelma differs from Citharacanthus in the male by the more apically wide embolus, the lack of tibial apophyses, and in both sexes on anterior podomeres by the lack of sectioned stridulatory setae on prolateral coxae of legs and the lack of metatarsal scopulae on leg IV. Acentropelma differs from Pseudoschizopelma gen.rest. in the male by the embolus with prolateral keelation near the apex more pronounced, and the lack of any tibial structures which in Pseudoschizopel$m a$ gen.rest. remain with a single extension of the cuticle leading to a megaspine. Acentropelma differs from Longilyra [which is presently only described/known from females] on anterior podomeres by the lack of liriform stridulatory setae on the trochanters. It differs from probable male Longilyra congeners (examined during this study although undescribed which share such modified anterior podomeres with both described and undescribed females) by the weaker prolateral keelation of the embolus, lack of tibial apophyses, and absence of metatarsal scopulae on leg IV. Acentropelma differs from Metriopelma in the male by the embolus lacking a tegular heel. Acentropelma differs from Central American "Lasiodora" [sensu lato] which in the male can have a similar embolus and also similarly lack tibial apophyses by the morphology of the stridulatory setae on the anterior podomere bases (see Galletti-Lima \& Guadanucci, 2018), and the absence of metatarsal scopulae on leg IV. Acentropelma differs from Neischnocolus in the male by the embolus lacking prolateral keelation basally, lack of tibial apophyses, but also by the lack of any pronounced retrolateral nodule on the palpal tibia and comparatively high number of labial cuspules (cf. Pérez-Miles, Gabriel \& Sherwood, 2019).

SPECIES INCLUDED. A. spinulosum (F.O. PickardCambridge, 1897) and A. gutzkei (Reichling, 1997).

DISTRIBUTION. Guatemala and Belize

\section{Acentropelma spinulosum \\ (F.O. Pickard-Cambridge, 1897)}

Figs 1-6, 27.

Metriopelma spinulosum F.O. Pickard-Cambridge, 1897: 33, pl. 2, f. 12; Rudloff, 1997: 2, 4 84.

Acentropelma spinulosum: Pocock, 1901: 555; Gabriel, 2016:

Stichoplastus spinulosus: Simon, 1903: 930; Smith, 1986: 99, f. 108h; 1987: 99, f. 108h.

TYPE MATERIAL: Holotype $\sigma^{7}$ Metriopelma spinulosum (BMNH 1898.12.24.65), Guatemala, Departamento Petén, "Petaxcatum"; leg. Francis Sarg, (labelled inside jar as "Type ${ }^{\text {" }}$. 65-3 Sarg: Petaxcatum, Guatemala"), examined; paratype $\sigma^{\prime \prime}$ Metriopelma spinulosum (OUMNH, Jar 59), Guatemala, Departamento Alta Verapaz, Finca Chicojoito near San Domingo de Cobán; Leg. Francis Sarg and Hans von Türckheim, Pickard-Cambridge coll. (labelled inside jar as "1409. Sarg: Guat. Chicozoito, H.V.Turck"), examined.

OTHER MATERIAL EXAMINED: $2 \sigma^{\top} \sigma^{\top}$ (ZMB 32213), GUATEMALA, det. R. Gabriel, 29 April 2013. 
5

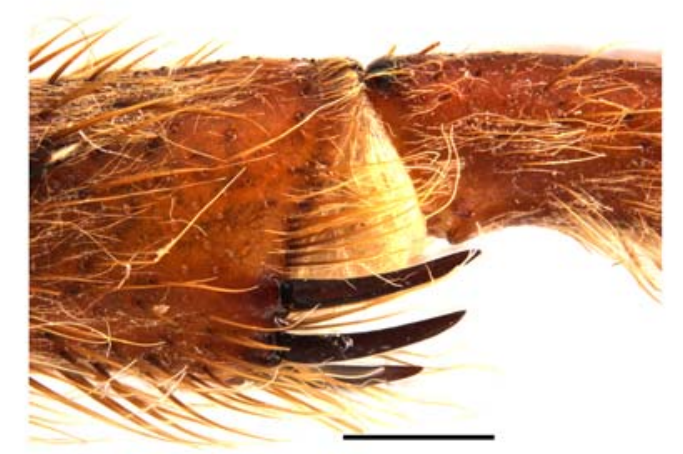

6

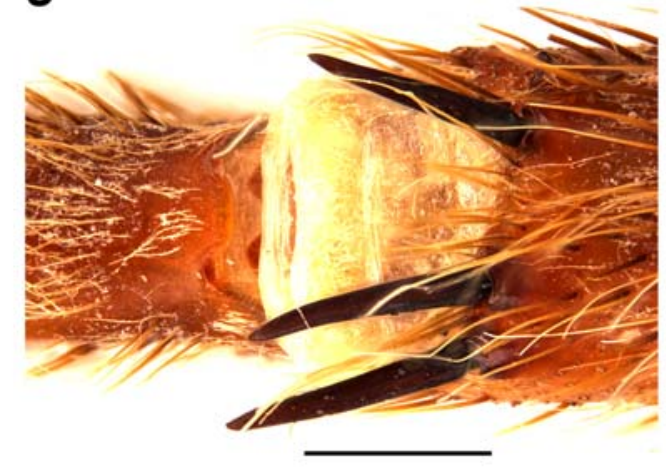

Figs. 5-6. Acentropelma spinulosum holotype male (BMNH/NHMUK), tibial apophysis: 5 - prolateral view; 6 - ventral (Note: one of apical spines has broken away). Scale lines $=1 \mathrm{~mm}$.

Рис. 5-6: Acentropelma spinulosum, самец голотип (BMNH/NHMUK), апофиз голени: 5 - пролатерально; 6 - снизу (один из апикальных шипов сломан и отсутствует). Масштаб 1 мм.

DIAGNOSIS. A. spinulosum can be distinguished from A. gutzkei in the male embolus by the former having a pronounced prolateral keelation near the apex (Fig. 1), and where the prolateral and subapical keel remain separated and relatively parallel as they move basally away from the apex (Figs 1, 3). A. spinulosum can be further distinguished from $A$. gutzkei in the male by spines on the distal ventral tibia I being robust (Figs 5-6), and the sternum with only a moderate posterior extension between coxae IV. Further distinguished from other genera and species as per the generic diagnosis.

DESCRIPTION. Holotype male (BMNH/NHMUK): Total length including chelicerae 29.3. Carapace: length 12.2, width. 11.2 Caput slightly raised, eye tubercle raised, length 1.4 width 2.0, Anterior eye row procurved, posterior row slightly recurved, eyes ALE < AME, AME $>$ PLE, PLE $>$ PME. Clypeus narrow, clypeal fringe long. Fovea deep, transverse. Abdomen: length 11.2, width 8.0. Chelicerae: length 5.9, width 4.2. Maxillae: with 100-120 cuspules covering approximately $60 \%$ of the proximal edge. Labium: length 1.5 , width 2.1 , with $60-80$ cuspules mostly separated by $0.5-1.5$ times the width of a cuspule. Labio-sternum mounds joined. Sternum: length 5.0, width 5.0, with three pairs of sigilla all ovate with posterior pair largest. Tarsi IIII fully scopulate, tarsi IV divided their entire length. Metatarsal scopulae: I 95\%; II 45\%, III, 18\% IV ascopulate. Lengths of legs and palpal segments see Table 1, legs 4,1,2,3. Spination: femur, I d $0-0-1$, II d $0-0-1$, III d 0-0-1, palp 0 $0-1$, tibia, I d $0-1-1$, v $0-2-5$ (4 apical), II d 1-1-0, v 0-34 (2 apical), III d 2-2-0, v 0-2-3 (apical), IV d 2-2-1, v 0

Table 1. Acentropelma spinulosum, holotype male (BMNH/NHMUK), legs and palp measurements.

Таблица 1. Acentropelma spinulosum, самец голотип (BMNH/NHMUK), размеры пальп и ног.

\begin{tabular}{|c|c|c|c|c|c|}
\hline & I & II & III & IV & Palp \\
\hline Femur & 11.7 & 10.9 & 9.9 & 12.2 & 7.3 \\
\hline Patella & 5.8 & 5.4 & 4.4 & 4.5 & 4.2 \\
\hline Tibia & 9.2 & 7.9 & 7.8 & 10.2 & 6.4 \\
\hline Metatarsus & 8.7 & 8.7 & 10.7 & 14.8 & - \\
\hline Tarsus & 6.2 & 6.1 & 5.3 & 6.3 & 1.2 \\
\hline Total & 41.6 & 39.0 & 38.1 & 48.0 & 19.1 \\
\hline
\end{tabular}

2-3 (apical), palp v 0-0-2, metatarsus, I v 1-0-1 (apical), II v 1-0-3 (apical), III d 1-2-3 (2 apical), v 1-4-4 (2 apical), IV d 1-2-3, v 4-4-6 (3 apical). Palpal bulb with developed RS, PS, SA and A keels, SA keel weakly denticulate (Figs 1-4). Tibia I with four slightly stout, basally incrassate spines at the ventral apex (Figs 5-6). Slight swelling on retrolateral palpal tibia. Prolateral trochanter and femur of leg I with soft-minutely plumose bristles, retrolateral trochanter of palp also with soft-minutely plumose bristles. Posterior lateral spinnerets with three segments, basal 2.6, median 1.5, digitiform apical 1.7; lateral median spinnerets with one segment. Urticating setae: Type I present. Colour: Alcohol preserved brown.

Paratype male (OUMNH): Total length including chelicerae 24.0. Carapace: length 10.2, width. 9.8 Caput slightly raised, eye tubercle raised, length 1.4 width 1.8, Anterior eye row procurved, posterior row slightly recurved, eyes ALE < AME, AME > PLE, PLE > PME. Clypeus narrow, clypeal fringe long. Fovea deep, transverse. Abdomen: length 11.1, width 7.1. Chelicerae: length 5.2, width 4.1. Maxillae: with $>80$ cuspules covering approximately $60 \%$ of the proximal edge. Labium: length 1.3 , width 1.2 , with $>70$ cuspules mostly separated by $0.5-1.5$ times the width of a cuspule. Labio-sternum mounds joined. Sternum: length 4.2, width 4.4 , with three pairs of sigilla all ovate with posterior pair largest. Tarsi I-III fully scopulate, tarsi IV divided their entire length. Metatarsal scopulae: I 95\%; II 56\%, III, > 20\% IV ascopulate. Lengths of legs and palpal segments see Table 2, legs 4,1,2,3. Spination: femur, I d 0-0-1, III d 0-0-

Table 2. Acentropelma spinulosum, paratype male (OUM$\mathrm{NH})$, legs and palp measurements.

Таблица 2: Acentropelma spinulosum, самец паратип (OUMNH), размеры пальп и ног.

\begin{tabular}{|c|c|c|c|c|c|}
\hline & I & II & III & IV & Palp \\
\hline Femur & 10.1 & 9.5 & 8.2 & 10.3 & 5.9 \\
\hline Patella & 5.0 & 4.5 & 4.1 & 4.1 & 3.6 \\
\hline Tibia & 7.7 & 7.1 & 6.4 & 8.9 & 6.0 \\
\hline Metatarsus & 7.3 & 7.2 & 8.8 & 12.3 & - \\
\hline Tarsus & 5.3 & 4.6 & 4.7 & 5.3 & 1.5 \\
\hline Total & 35.3 & 32.9 & 32.2 & 40.9 & 17.0 \\
\hline
\end{tabular}



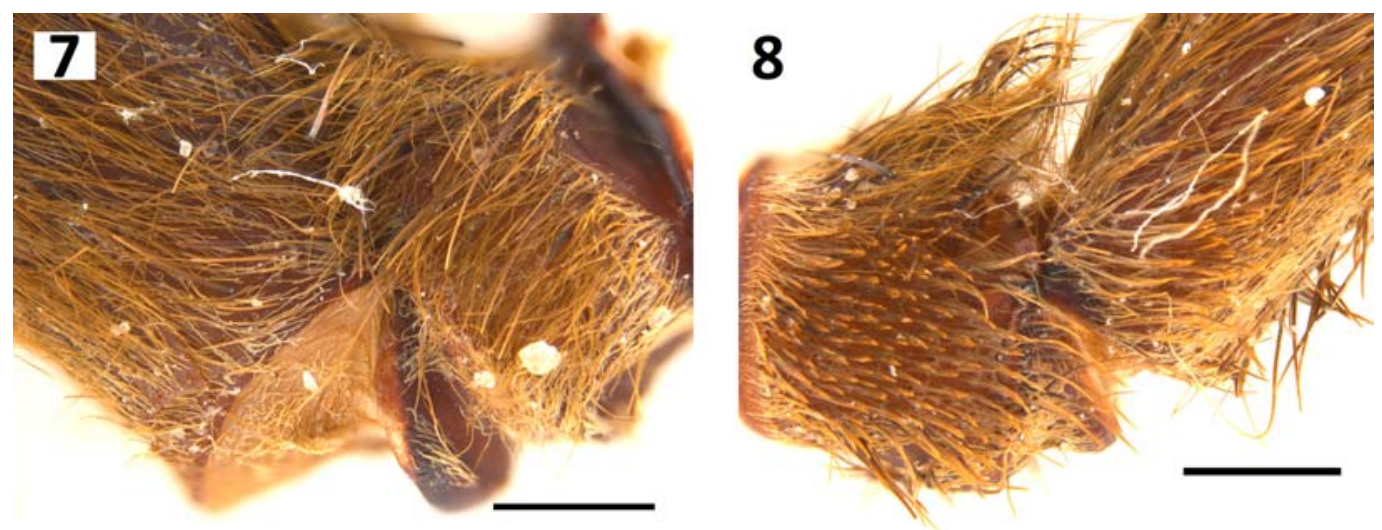

Figs. 7-8. Pseudoschizopelma gutzkei comb.n., holotype male (AMNH), plumose setae: 7 - prolateral view of femur and trochanter I; 8 - retrolateral view of palpal trochanter. Scale lines $=1 \mathrm{~mm}$.

Рис. 7-8. Pseudoschizopelma gutzkei comb.n., самец голотип (AMNH), перистые волоски: 7 -на бедре и вертлуге I, пролатерально; 8 - на вертлуге пальпы, ретролатерально. Масштаб 1 мм.

1, tibia, I d $0-1-1$, v $0-1-5$ (4 apical), II d $0-1-0$, v 1-2-4 (2 apical), III d 1-2-1, v 0-1-3 (apical), IV d 2-0-2, v 0-12 (apical), palp d $0-0-2$ v $0-1-1$, metatarsus, I d $0-1-0$, v 0-0-2 (apical), II v 0-2-3 (apical), III d 1-2-2 (2 apical), v 1-2-5 (4 apical), IV d 2-2-2, v 4-4-5 (3 apical). Palpal bulb with developed RS, PS, SA and A keels, SA keel weakly denticulate. Tibia I with four slightly, basally incrassate spines at the ventral apex. Slight swelling on retrolateral palpal tibia. Prolateral trochanter and femur of leg I with soft-minutely plumose bristles, retrolateral trochanter of palp also with soft-minutely plumose bristles. Posterior lateral spinnerets with three segments, basal 1.3, median 1.0, digitiform apical 1.8; lateral median spinnerets with one segment. Urticating setae: Type I present. Colour: Alcohol preserved brown.

DISTRIBUTION. Known from type locality of Petaxcatum [likely Petaxbatún, Departamento Petén] Guatemala and "Chicoyoito/Chicozoito" [ = Finca Chicojoito, near San Domingo de Cobán, Departamento Alta Verapaz], Guatemala (Fig. 27, see also discussion).

REMARKS. There seemed to be a mix up in the numbering of the jar labels between two male specimens of $A$. spinulosum referred to by F.O. Pickard-Cambridge [1897: 33-34]. The BMNH specimen as originally described in his text appears to match his "(no.1409) at Petaxcatum by $\mathrm{Mr}$ Sarg" [F.O. Pickard-Cambridge, 1897], but that is now linked to the number $65-3$ on its current labelling. His text further says the specimen from this locality is "is taken as the type". Conversely, the OUMNH specimen is labelled as "1409" and "Chicozoito", while the original description says another male as "(no. 653) at Chicoyoito". Together, this numbering confusion may cast some doubt as to which of the two males should be the holotype. After re-examination of both, the BMNH specimen best matches the measurements given in the description. The BMNH specimen is also annotated as 'type' on both an old label within the jar and in the corresponding accession book, plus retains the original specified location of Petaxcatum as type locality. It was also considered the holotype by Gabriel [2016], and likely other workers who focused on BMNH specimens (i.e. Pocock, 1901). We therefore conclude that F.O. Pickard-Cambridge [1897] simply made a typographical error about the reference numbering, or whoever dealt with accession and labelling of these specimens, and we suggest the OUMNH specimen is best considered as the paratype. This may at first seem confusing since Pickard-Cambridge [1897] states "The latter is taken as type" (suggesting the OUMNH specimen might be the holotype). Article 73.1.1. of the ICZN [1999] states that: "If an author when establishing a new nominal species-group taxon states in the original publication that one specimen, and only one, is the holotype, or «the type», or uses some equivalent expression, that specimen is the holotype fixed by original designation." but here, we consider that the confusion made by Pickard-Cambridge [1897] casts into doubt that he fixed "only one" specimen, as he may have confused museum numbers and thus, in turn, the two specimens themselves, even between each other in the same description. This hypothesis is further supported by the measurements of the "type" being more consistent with the BMNH specimen than the OUMNH specimen. Thus, we regard the BMNH specimen as the holotype. The numbers indicated in these two specimens should not be confused as museum accession numbers for these specimens in their respective institutions, as this is not the case. The female of A. spinulosum is currently unknown.

At present, we have not been able to locate a precise modern location for "Petaxcatum" but we believe this likely corresponds to modern Petaxbatún, in the southern part of Petén (approximately $16^{\circ} 26^{\prime} 35^{\prime \prime} \mathrm{N}, 90^{\circ} 10^{\prime} 50^{\prime \prime} \mathrm{W}$ ). However, given the named collector was mostly based in Alta Verapaz region, we consider another currently unknown location within that latter department is also plausible. The locality of the second specimen mentioned by F.O. Pickard-Cambridge [1897] from "Chicoyoito", does not appear to correspond to any modern location, but instead can be linked to a historic coffee farm owned by a brother of the collector in the highlands of Alta Verapaz, where a better spelling may be 'Chicojoito" (see Wagner \& von Rothkirch, 2001), in the close vicinity of Cobán (Fig. 27).

\section{Acentropelma gutzkei (Reichling, 1997)} Figs 7-12, 27.

Crypsidromus gutzkei Reichling, 1997: 49, f. 1-4.

Lasiodora gutzkei Pérez-Miles et al., 1996: 52.

Acentropelma gutzkei: Gabriel, 2016: 84.

TYPE MATERIAL: Holotype $0^{7}$ Crypsidromus gutzkei (AMNH), Belize, Central America, Indian Church Village, Orange 


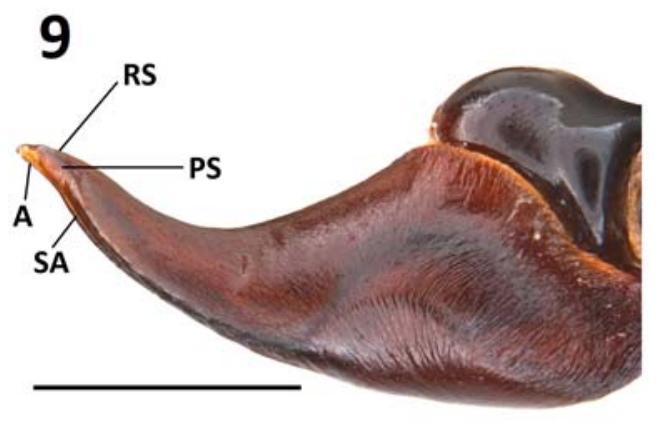

11

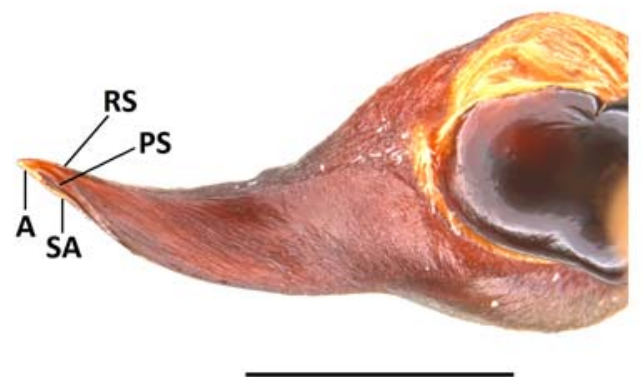

10

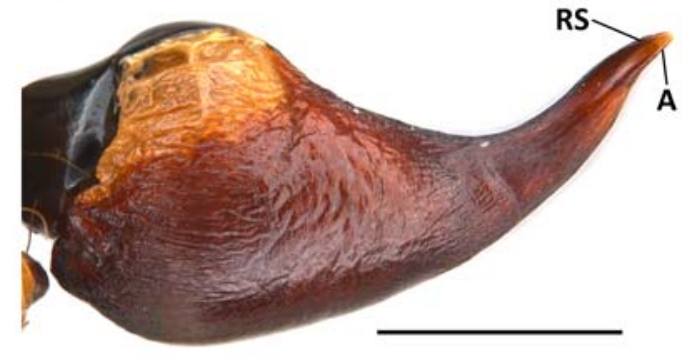

12

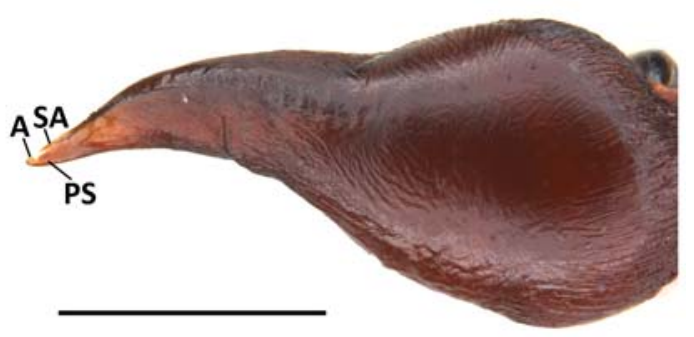

Figs. 9-12. Pseudoschizopelma gutzkei comb.n., holotype male (AMNH), palpal bulb (right hand side): 9 - prolateral view; 10 retrolateral; 11 - dorsal; 12 - ventral. Scale lines $=1 \mathrm{~mm}$.

Рис. 9-12. Pseudoschizopelma gutzkei comb.n., самец голотип (AMNH), бульбус пальпы (правая пальпа): 9 - пролатерально; 10 - ретролатерально; 11 - сверху; 12 - снизу. Масштаб 1 мм.

Walk District, 0.1 km W New River Lagoon, 1 October 1995, Coll. S.B. Reichling, examined.

DIAGNOSIS. A. gutzkei can be distinguished from $A$. spinulosum in the male embolus by the former having a quite inconspicuous prolateral keelation near the apex (Fig. 9), where the prolateral and subapical keels soon converge as they move basally away from the apex (Figs 9 and 11). $A$. gutzkei can be further distinguished from A. spinulosum in the male by spines on the distal ventral tibia I not being robust, and the sternum with a pronounced posterior extension between coxae IV. Further distinguished from other genera and species as per the generic diagnosis.

DESCRIPTION. Holotype male (AMNH): [as the original description is satisfactory only features not mentioned or fully explored will be included here] Posterior lateral spinnerets with three segments: basal 1.2, medial 1.6, digitiform apical 1.8. Lateral median spinnerets with one segment Palpal bulb with developed RS, PS, SA and A keels, SA keel denticulate (Figs 9-12). Prolateral trochanter and femur of leg I with soft-minutely plumose bristles, retrolateral trochanter of palp also with soft-minutely plumose bristles. Urticating setae: Type I present. Colour: alcohol preserved brown.

DISTRIBUTION. Only known from the type locality, Indian Church Village, Orange Walk District, $0.1 \mathrm{~km} \mathrm{~W}$ New River Lagoon, Belize (Fig. 27).

REMARKS. The presence of plumose setae on the prolateral trochanter of leg I and the retrolateral palpal trochanter went unnoticed in the original description, only being noted in Gabriel [2016]. Reichling [1997] notes that the holotype lacks scopulae on metatarsus IV but seemingly did not recognise the significance of this character, which is uncommon for the Theraphosinae. Furthermore, Reichling
[1997: 49] states "The immaculate clothing of bright red setae on the abdomen of the holotype male is generically unique and distinguishes C. gutzkei from all Central and South American congeners with unpatterned abdomens". However, many species in several theraphosine genera from North, Central and South America also possess a dense covering of bright red setae on the abdomen whilst simultaneously lacking a pattern, so neither aspect is particularly useful as a diagnostic feature. Due to long term preservation in spirit, the holotype is now indistinctly brown in colouration. Furthermore, the condition of the holotype in general is not ideal, the specimen is severely fragmented.

\section{Genus Pseudoschizopelma Smith, 1995 gen.rest.}

Pseudoschizopelma Smith, 1995: 185.

Cyclosternum: Pérez-Miles et al., 1996: 46 (in part).

Acentropelma: Gabriel, 2016: 84 (in part).

TYPE SPECIES: Pseudoschizopelma macropus (Ausserer, 1875) by original designation.

DIAGNOSIS. Pseudoschizopelma gen.rest. can be distinguished from other Theraphosinae genera largely by the combination of divergent aspects of the genital organs and the absence of tibial apophyses in the male. Pseudoschizopel$m a$ can be further differentiated from most other genera (except some such as Acentropelma) by setal structures of anterior podomere bases with only plumose stridulatory setae on the prolateral trochanter and proximal femur of leg I plus the retrolateral palpal trochanter. As for Acentropelma, we focus diagnosis on select genera that can be closely related due to similar morphology as well as being geographically close or overlapping in distribution. Pseudoschizopelma differs from other genera especially by the form 
13

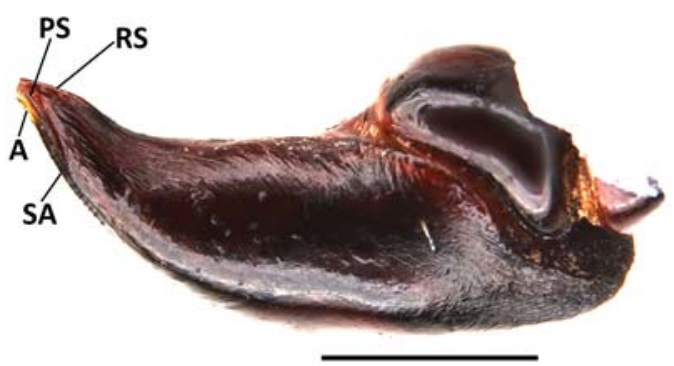

15

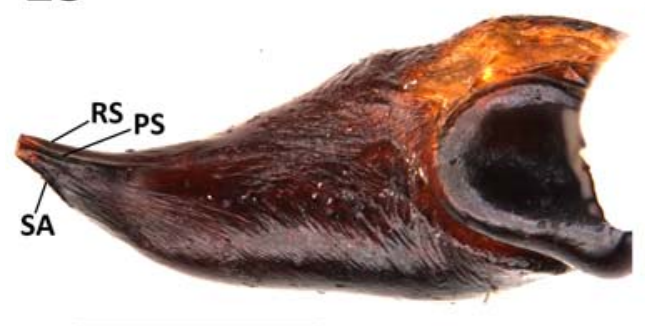

14

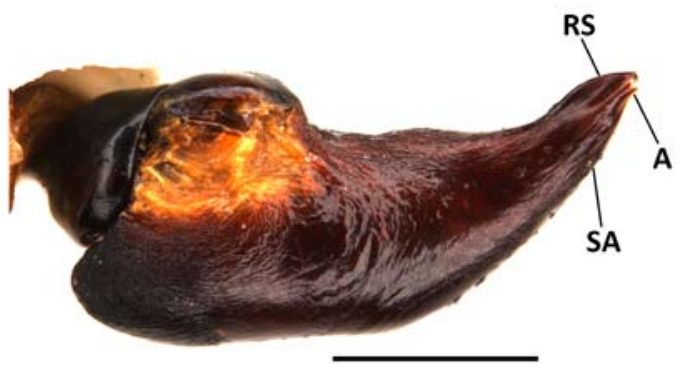

16

RS

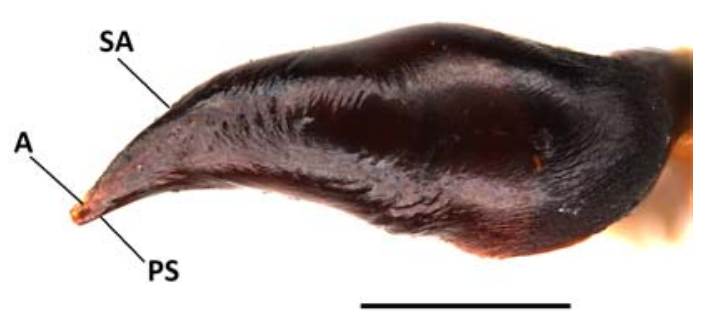

Figs. 13-16. Pseudoschizopelma macropus comb.rest., holotype male (BMNH/NHMUK), palpal bulb (right hand side): 13 prolateral view; 14 - retrolateral; 15 - dorsal; 16 - ventral. Scale lines $=1 \mathrm{~mm}$.

Pис. 13-16. Pseudoschizopelma macropus comb.rest., самец голотип (BMNH/NHMUK), бульбус пальпы (правая пальпа): 13 пролатерально; 14 - ретролатерально; 15 - сверху; 16 - снизу. Масштаб 1 мм.

of the embolus and its keelation (Figs 13-16, 20-23) and specifically differs from other genera as given in the diagnosis of Acentropelma. Pseudoschizopelma also differs from most genera by the lack of tibial apophyses (albeit with some unique associated modification, see Figs 17-18, 24 25) except for Metriopelma or Central America Lasiodora [sensu lato], both of which can be differentiated as in the diagnosis of Acentropelma. Additionally as the female is known, Pseudoschizopelma can be distinguished from most other genera in the female by the two elongate spermathecal receptacles each emergent from membranous base with a narrowed neck and single oval lobe at apex, except from some Citharacanthus and Central America Lasiodora which can be distinguished in both sexes by the absence of scopulae on ventral metatarsus IV in Pseudoschizopelma. Furthermore, Pseudoschizopelma can be further differentiated in both sexes from most other genera by this same aspect, and/ or the presence of plumose stridulatory setae on anterior podomere bases, with exceptions as given for Acentropelma. Pseudoschizopelma differs from Acentropelma in the male by the embolus with prolateral keelation near the apex less pronounced. Furthermore, although both genera are deemed to lack of any tibial apophyses on leg I, in Pseudoschizopelma here each ventral tibia instead possess a single extension of the cuticle with an apical megaspine (the latter aspect being lost on examined historical material, see below). It could be argued this represents a weak form of apophyses but this is not concretely established with the current data and requires considerable future research, including likely Scanning Electron Microscopy analysis. Thus, here we make the distinction until evidence shows otherwise.

SPECIES INCLUDED. P. macropus comb.rest.

\section{DISTRIBUTION. Mexico.}

REMARKS. Smith [1995] designated A. macropus as the type species of his new genus Pseudoschizopelma but did not realise the jar containing this species also contained appendages from a heterogeneric specimen. As a result, whilst he designated A. macropus as the type species he illustrated the palpal bulb, leg I tibial apophysis and leg IV (ventral face) of a divergent specimen and thus his diagnosis and illustrations of male morphological features are not representative of the correct specimen. Whilst this error is significant, it has no effect on the availability of the genus (Alain Dubois pers. comm. to DS), as Smith designated the whole (correct) male specimen as the name bearing type, which satisfies nomenclatural practice [ICZN, 1999].

\section{Pseudoschizopelma macropus (Ausserer, 1875) comb.rest. \\ Figs 13-27.}

Crypsidromus macropus Ausserer, 1875: 179, pl. 6, f. 24-25. Schizopelma macropus: F.O. Pickard-Cambridge, 1897: 29, pl. 1 , f. 10 . 1040.

Pseudoschizopelma macropus: Smith, 1995: 187, f. 1034-

Schizopelma sorkini Smith, 1995: 191, f. 1083-1100, syn.n.

Cyclosternum macropus: Pérez-Miles et al., 1996: 46, f. 15. $2,9$.

Davus macropus: Schmidt, 2003: 162, f. 350-351; 2005: 14, f.

Acentropelma macropus: Gabriel, 2016: 84.

Acentropelma sorkini: Gabriel, 2016: 85.

TYPE MATERIAL: Holotype $\sigma^{\prime}$ Metriopelma macropus (BMNH 1890.7.1.348), "Pic d' Orizaba" (= Pico de Orizaba, Estado Puebla), Mexico, examined; paratype 9 (same data), examined; holotype ${ }^{7}$ Schizopelma sorkini (BMNH 90.7.1-349), St. Andres 

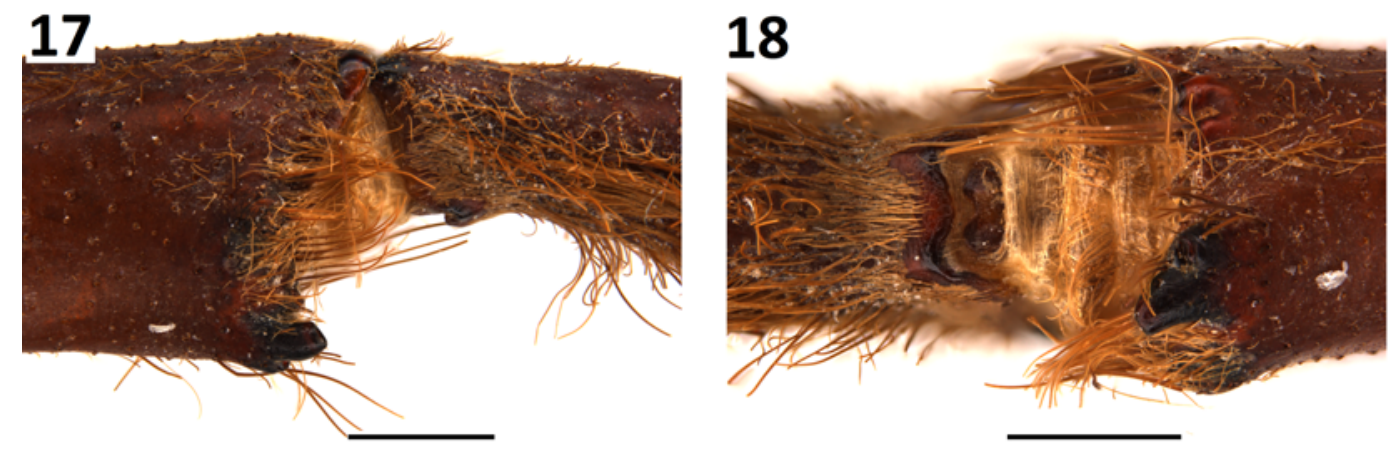

Figs. 17-18. Pseudoschizopelma macropus comb.rest., holotype male (BMNH/NHMUK), tibial apophysis, 17 — prolateral view; 18 ventral. Scale lines $=1 \mathrm{~mm}$.

Рис. 17-18: Pseudoschizopelma macropus comb.rest., самец голотип (BMNH/NHMUK), апофиз голени, 17 — пролатерально; 18 снизу. Масштаб 1 мм.

(uncertain location - see below), Mexico, examined; paratype of Schizopelma sorkini (designated by Smith, 1995), (same data, but not conspecific to holotype, misidentified Brachypelma sp.), examined.

OTHER MATERIAL EXAMINED: 2 우, $20^{7} \sigma^{7}$ subad. (BMNH 1890.7.1-349), Mexico, St Andres.

DIAGNOSIS. P. macropus comb.rest. is considered monotypic, and other taxa can be distinguished following the generic diagnosis. It can be distinguished from those of Acentropelma in the male embolus by the less pronounced prolateral keelation, particularly compared to A. spinulosum, or by the proportionally wider apex of the embolus in comparison to A. gutzkei, Else, the male of P. macropus can be distinguished from both species of Acentropelma by the single extension of the cuticle with an apical megaspine on tibia I, and can be further distinguished from A. gutzkei by the sternum with only a moderate posterior extension between coxae IV.

DESCRIPTION. Holotype male [of P. macropus] (BMNH/NHMUK): Total length including chelicerae 26.4. Carapace: length 10.0, width. 7.0. Caput slightly raised, eye tubercle raised, length 1.4 width 2.0, Anterior eye row procurved, posterior row slightly recurved, eyes ALE $<$ AME, AME $>$ PLE, PLE > PME. Clypeus narrow, clypeal fringe long. Fovea deep, transverse. Abdomen: length 10.0, width 7.0. Chelicerae: length 6.2 width 5.2. Maxillae: with $60-70$ cuspules covering approximately $33 \%$ of the proximal edge. Labium: [unable to interpret due to condition of specimen]. Labio-sternum mounds: [unable to interpret due to condition of specimen]. Sternum: [unable to interpret due to con-

Table 3. Pseudoschizopelma macropus comb.rest., holotype male (BMNH/NHMUK), legs and palp measurements, asterisk indicates leg segments that could not be allocated.

Таблица 3. Pseudoschizopelma macropus comb.rest., самец голотип (BMNH/NHMUK), размеры пальп и ног, звездочкой обозначены сегменты ног, локализация которых не может быть точно установлена.

\begin{tabular}{|c|c|c|c|c|c|}
\hline & I & II & III & IV & Palp \\
\hline Femur & $*$ & $*$ & $*$ & 12.1 & 7.4 \\
\hline Patella & 6.2 & $*$ & $*$ & 5.2 & 4.6 \\
\hline Tibia & 10.0 & $*$ & $*$ & 10.5 & 6.8 \\
\hline Metatarsus & 9.0 & $*$ & $*$ & 14.8 & - \\
\hline Tarsus & 6.8 & $*$ & $*$ & 7.4 & 1.3 \\
\hline Total & N/A & N/A & N/A & 50.0 & 20.1 \\
\hline
\end{tabular}

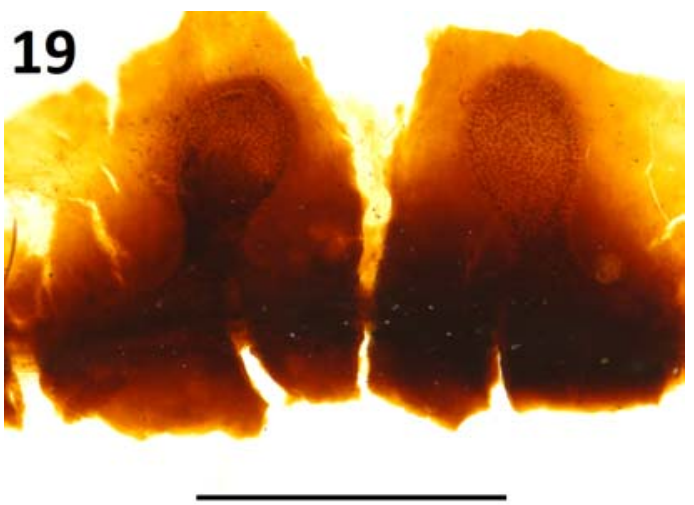

Fig. 19. Pseudoschizopelma macropus comb.rest., paratype female $(\mathrm{BMNH} / \mathrm{NHMUK})$, spermathecae, dorsal view. Scale line $=$ $1 \mathrm{~mm}$.

Рис. 19. Pseudoschizopelma macropus comb.rest., самка паратип (BMNH/NHMUK), сперматеки, сверху. Масштаб 1 мм.

dition of specimen]. Tarsi I-IV fully scopulate. Metatarsal scopulae: I 96\%; IV ascopulate. Lengths of legs and palpal segments [some damaged or unallocatable] see Table 3. Spination: tibia I d $0-0-1$, v $0-1-0$, IV d 1-2-2 (apical), v 0-1-4 (1 apical), metatarsus I v 1-0-2 (apical), IV d 4-4-6 (3 apical). Palpal bulb with developed RS, PS, SA and A keels, SA keel denticulate (Figs 13-16). Tibia I with four spines [only sockets present due to condition of specimen] (Figs 17-18). Prolateral trochanter and femur of leg I with plumose bristles, retrolateral trochanter of palp also with plumose bristles. Posterior lateral spinnerets with three segments, [unable to interpret due to condition of specimen]; lateral median spinnerets with one segment. Urticating setae: Type I present. Colour: alcohol preserved brown.

Allotype female [of P. macropus] (BMNH/NHMUK): Total length including chelicerae 34.9. Carapace: length 12.5, width 10.3. Caput slightly raised, eye tubercle raised, length 1.4 width 2.0, Anterior eye row procurved, posterior row slightly recurved, eyes ALE < AME, AME $>$ PLE, PLE $>$ PME. Clypeus narrow, clypeal fringe long. Fovea deep, transverse. Abdomen: length 17.8, width 10.3. Chelicerae: length 7.1 width 6.0. Maxillae: with 40-50 cuspules covering approximately $39 \%$ of the proximal edge. Labium: length 1.6, width 2.7 , with $80-100$ labial cuspules most separated by $0.5-1$ times the width of a single cuspule. Labio-sternum mounds: [unable to interpret due to condition of specimen]. 
20

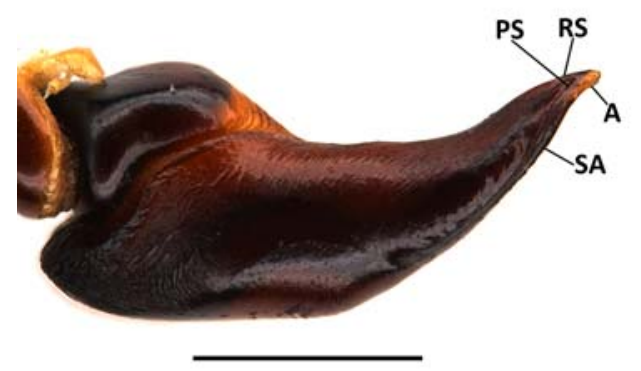

22

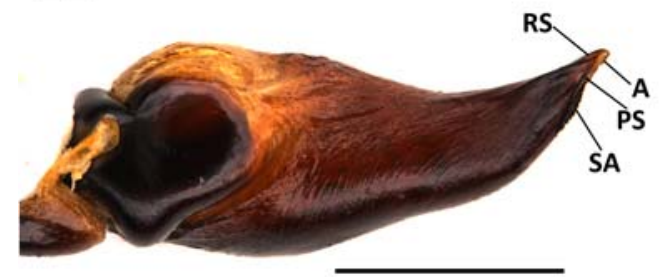

21

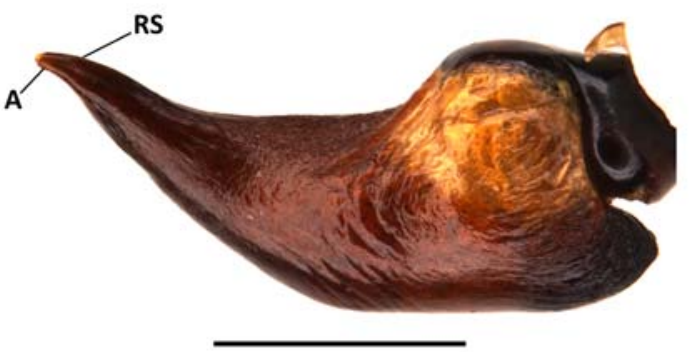

23

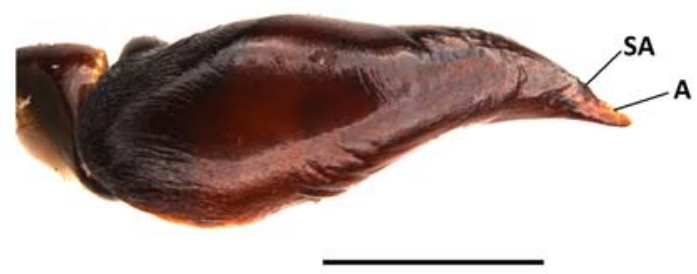

Fig. 20-23. Pseudoschizopelma macropus comb.rest. [holotype male of A. sorkini] (BMNH/NHMUK), palpal bulb (left hand side), 20 - prolateral view; 21 - retrolateral; 22 - dorsal; 23 - ventral. Scale lines $=1 \mathrm{~mm}$.

Pис. 20-23. Pseudoschizopelma macropus comb.rest. [A. sorkini, самец голотип] (BMNH/NHMUK), бульбус пальпы (левая пальпа), 20 - пролатерально; 21 - ретролатерально; 22 - сверху; 23 - снизу. Масштаб 1 мм.

Sternum: [unable to interpret due to condition of specimen]. Tarsi I-IV fully scopulate. Metatarsal scopulae: I 36\%; IV ascopulate. Lengths of legs and palpal segments [some damaged or unallocatable] see Table 4. Spination: femur, IV d $0-0-1$, palp d $0-0-1$, patella palp d $0-1-1$, v $0-1-4$ (apical), tibia IV d 0-1-3 (1 apical), v 0-1-4 (apical), metatarsus I v $0-0-3$ (apical, IV d 0-2-2 (apical), v 0-0-3 (apical). Spermathecae: Spermathecae with two elongate receptacles, each emergent from membranous base with a narrowed neck and single oval lobe at apex (Fig. 19). Prolateral trochanter and femur of leg I with plumose bristles, retrolateral trochanter of palp also with plumose bristles. Posterior lateral spinnerets with three segments, [unable to interpret due to condition of specimen]; lateral median spinnerets with one segment. Urticating setae: Type I present. Colour: alcohol preserved brown.

Table 4. Pseudoschizopelma macropus comb.rest., paratype female (BMNH/NHMUK), lengths legs and palp measurements, asterisk indicates leg segments that could not be allocated.

Таблица 4. Pseudoschizopelma macropus comb.rest., paratype female (BMNH/NHMUK), размеры пальп и ног,

звездочкой обозначены сегменты ног, локализация которых не может быть точно установлена.

\begin{tabular}{|c|c|c|c|c|c|}
\hline & I & II & III & IV & Palp \\
\hline Femur & 8.0 & $*$ & $*$ & 9.3 & 6.3 \\
\hline Patella & 5.1 & $*$ & $*$ & 4.7 & 4.2 \\
\hline Tibia & 5.6 & $*$ & $*$ & 7.5 & 5.0 \\
\hline Metatarsus & 5.8 & $*$ & $*$ & 10.3 & - \\
\hline Tarsus & 5.4 & $*$ & $*$ & 5.1 & 5.0 \\
\hline Total & 29.9 & N/A & N/A & 36.9 & 20.5 \\
\hline
\end{tabular}

Holotype male [of $A$. sorkini] (BMNH/NHMUK): Total length including chelicerae 20.7. Carapace: length 9.3, width. 8.0. Caput slightly raised, eye tubercle raised, length 1.0 width 1.6, Anterior eye row procurved, posterior row slightly recurved, eyes ALE $<$ AME, AME $>$ PLE, PLE $>$ PME. Clypeus narrow, clypeal fringe long. Fovea deep, slightly recurved. Abdomen: length 7.5, width 4.5. Chelicerae: length 3.9, width 1.9. Maxillae: with 50-60 cuspules covering approximately $33 \%$ of the proximal edge. Labium: length 1,1 width 1.7 , with $70-90$ cuspules mostly separated by $0.5-1.5$ times the width of a cuspule. Labio-sternum mounds joined. Sternum: length 4.0, width 4.0, with three pairs of sigilla. Tarsi I-IV fully scopulate. Metatarsal scopulae: I 100\%; II $59 \%$, III, $25 \%$ IV ascopulate. Lengths of legs and palpal segments see Table 5, legs 4,1,2,3. Spination: tibia II v 0-03 (apical), III v $0-0-4$ (apical), IV v 0-0-3 (apical), palp v 0-1-1 (apical), metatarsus I d 0-0-2 (apical), II v 1-1-2

Table 5. Pseudoschizopelma macropus comb.rest. [holotype male of $A$. sorkini] (BMNH/NHMUK), legs and palp measurements.

Таблица 5. Pseudoschizopelma macropus comb.rest. [A. sorkini, самец голотип] (BMNH/NHMUK), размеры пальп и ног.

\begin{tabular}{|c|c|c|c|c|c|}
\hline & I & II & III & IV & Palp \\
\hline Femur & 8.9 & 9.1 & 7.8 & 9.9 & 5.7 \\
\hline Patella & 4.8 & 4.2 & 3.1 & 3.5 & 3.3 \\
\hline Tibia & 8.2 & 7.0 & 6.4 & 8.9 & 5.3 \\
\hline Metatarsus & 6.7 & 6.8 & 8.3 & 11.6 & - \\
\hline Tarsus & 4.9 & 4.9 & 4.6 & 5.3 & 1.4 \\
\hline Total & 33.5 & 32.0 & 30.2 & 39.2 & 15.7 \\
\hline
\end{tabular}



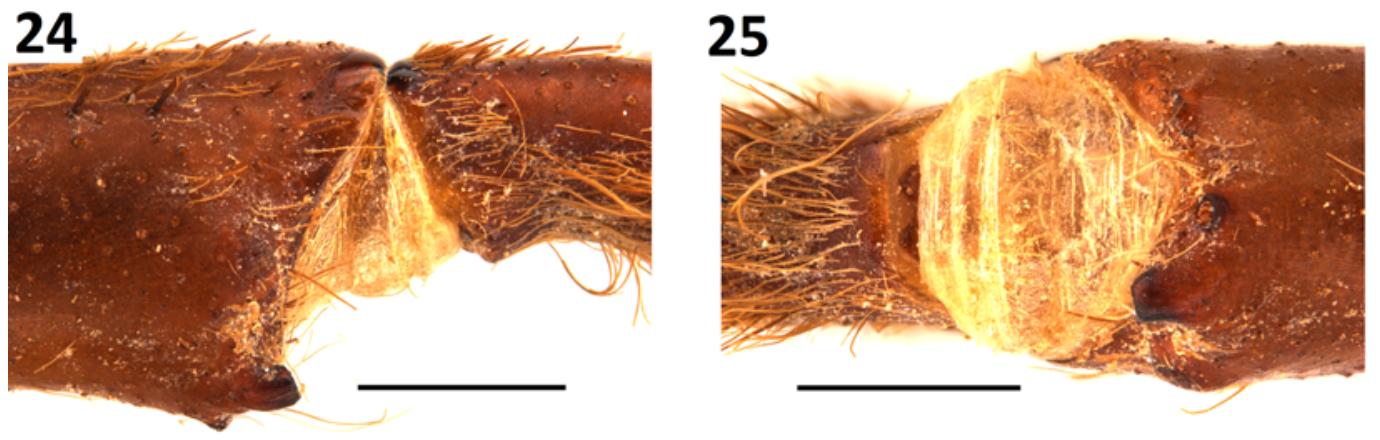

Figs. 24-25. Pseudoschizopelma macropus comb.rest. [holotype male of A. sorkini] (BMNH/NHMUK), tibial apophysis: 24 prolateral view; 25 - ventral. Scale lines $=1 \mathrm{~mm}$.

Рис. 24-25. Pseudoschizopelma macropus comb.rest. [A. sorkini, самец голотип] (BMNH/NHMUK), апофиз голени: 24 пролатерально; 25 - снизу. Масштаб 1 мм.

(apical), III v 2-0-4 (3 apical), IV d 0-0-2 (apical), v 4-2-4 (2 apical). Palpal bulb with developed RS, PS, SA and A keels, SA keel denticulate (Figs 20-23). Tibia I with two spines [only sockets present due to condition of specimen] (Figs 24-25). Prolateral trochanter and femur of leg I with plumose bristles, retrolateral trochanter of palp also with plumose bristles. Posterior lateral spinnerets with three segments, basal 1.6, median 1.0, digitiform apical missing; lateral median spinnerets with one segment. Urticating setae: Type I present. Colour: alcohol preserved brown.

Non-type female [of $A$. sorkini] (BMNH/NHMUK 1890.7.1-349): Total length including chelicerae 27.8. Carapace: length 14.4, width 10.7. Caput slightly raised, eye tubercle raised, length 1.1 width 2.0, Anterior eye row procurved, posterior row slightly recurved, eyes ALE $<$ AME, AME > PLE, PLE > PME. Clypeus narrow, clypeal fringe long. Fovea deep, slightly recurved. Abdomen: length 10.3, width 9.2. Chelicerae: length 3.1 width 2.0. Maxillae: with 60-70 cuspules covering approximately $34 \%$ of the proximal edge. Labium: length 1.2 , width 2.4 , with 50-60 labial cuspules most separated by $0.5-1$ times the width of a single cuspule. Labio-sternum mounds: joined. Sternum: length 4.2 , width 3.8 , with three pairs of sigilla. Tarsi I-IV fully scopulate. Metatarsal scopulae: I 100\%; II 61\%; III 37\%; IV ascopulate. Lengths of legs and palpal segments see Table 6 . Spination: tibia II v $0-1-0$, III d 0-0-2 (apical), IV d 0-0-2 (apical), palp $0-0-2$, metatarsus II v $0-0-1$ (apical), III d 0 0-2 (apical), v 2-2-2 (apical), IV d 0-2-2 (apical), v 5-5-4 (2 apical). Spermathecae with two elongate receptacles, each emergent from membranous base with a narrowed neck and

Table 6. Pseudoschizopelma macropus comb.rest. [nontype female of $A$. sorkini] (BMNH/NHMUK), legs and palp measurements.

Таблица 6. Pseudoschizopelma macropus comb.rest. [A. sorkini, самка не из типовой серии] (BMNH/NHMUK), размеры пальп и ног.

\begin{tabular}{|c|c|c|c|c|c|}
\hline & I & II & III & IV & Palp \\
\hline Femur & 8.3 & 6.9 & 6.2 & 7.5 & 4.9 \\
\hline Patella & 4.6 & 3.3 & 3.4 & 3.8 & 3.3 \\
\hline Tibia & 6.0 & 5.2 & 4.5 & 6.7 & 4.3 \\
\hline Metatarsus & 4.4 & 4.8 & 5.9 & 9.2 & - \\
\hline Tarsus & 3.5 & 4.2 & 3.2 & 4.0 & 4.4 \\
\hline Total & 26.8 & 24.7 & 23.2 & 31.2 & 16.9 \\
\hline
\end{tabular}

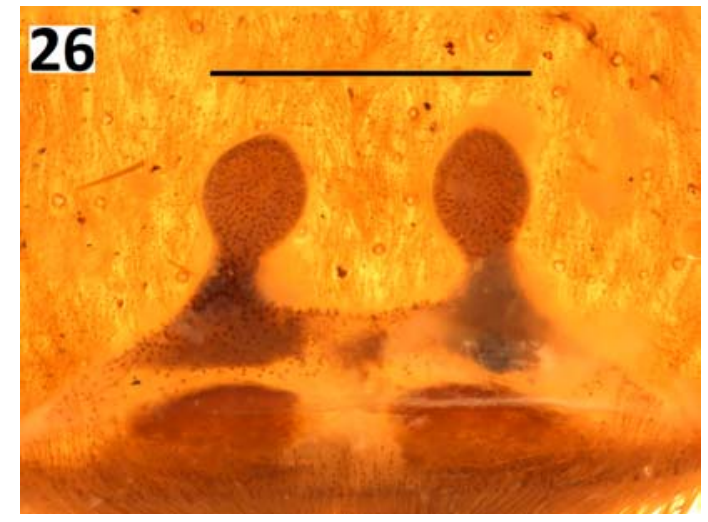

Figs. 26. Pseudoschizopelma macropus comb.rest. [non-type female in same specimen jar with male holotype of A. sorkini] (BMNH/NHMUK), spermathecae, dorsal view. Scale line $=1 \mathrm{~mm}$.

Рис. 26. Pseudoschizopelma macropus comb.rest. [нетиповая самка из одной банки с самцом голотипом A. sorkini] (BMNH/ NHMUK), сперматеки, сверху. Масштаб 1 мм.

single oval lobe at apex (Fig. 26). Prolateral trochanter and femur of leg I with plumose bristles, retrolateral trochanter of palp also with plumose bristles. Posterior lateral spinnerets with three segments, basal 1.8, median 1.3, digitiform apical 2.2; lateral median spinnerets with one segment. Urticating setae: Type I present. Colour: alcohol preserved brown. Note: Not the alleged allotype described by Smith [1995].

DISTRIBUTION. Pico de Orizaba, Estado Puebla, Mexico (Fig. 27) and St. Andres, Mexico (see Remarks).

REMARKS. Smith [1995] mentions two specimens are in the jar containing the holotype of $P$. macropus but only describes the male, making no other mention of the second specimen, a female, in his work. We consider this a paratype (and ergo refer to it as the allotype) as it was mentioned second in the original description [Ausserer, 1875]. Both specimens are ex-dried pinned specimens that are partially fragmented. Many measurements and features were not interpretable on both because the necessary parts were either too damaged to examine or were absent. Fortunately, the opisthosoma of the female had not been eviscerated (many dried specimens in the past had their abdomens eviscerated as a means of preservation to prevent rot) so the spermathecae was still present, but its poor condition necessitated examination in clove oil for this study. The palpal bulb and leg I tibial apophyses of the male were in fair condition, 


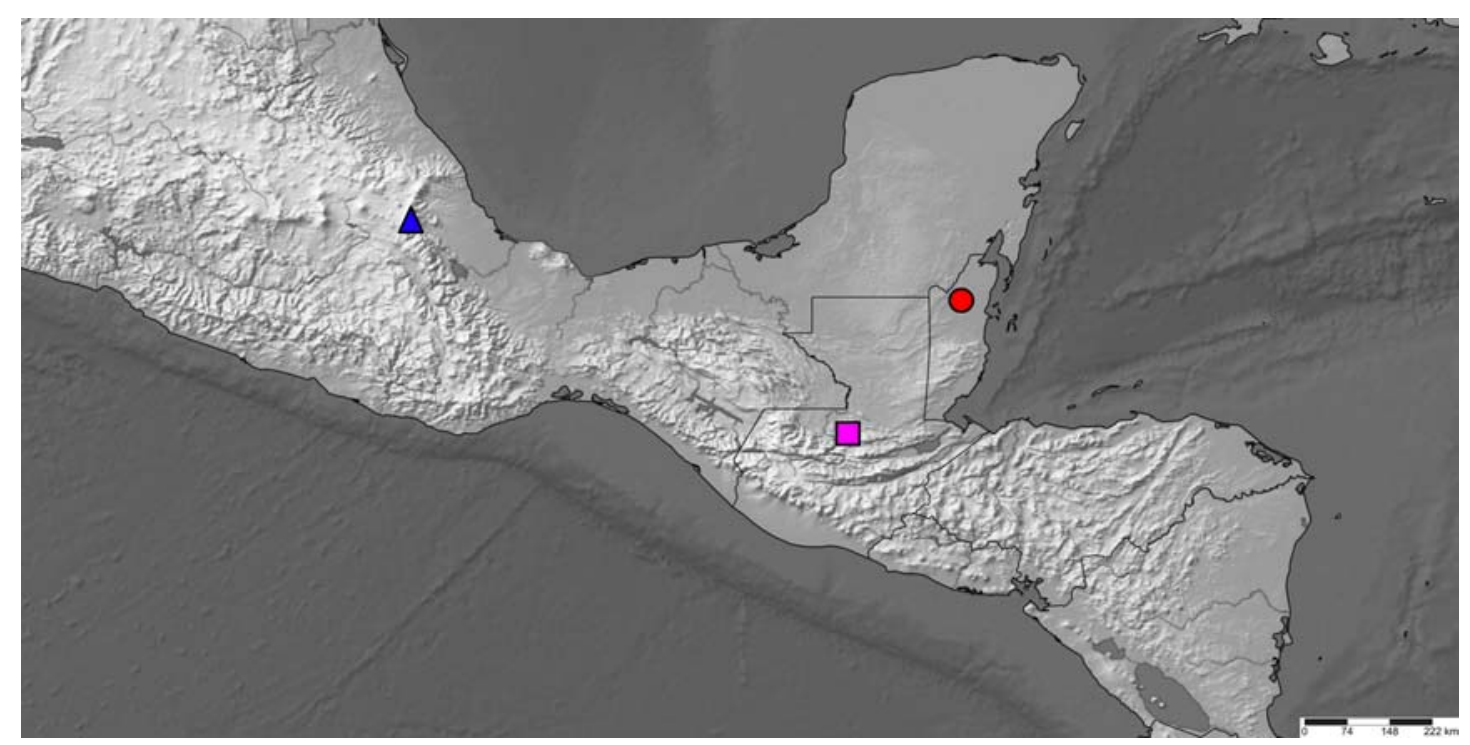

Fig. 27. Map of type localities of the valid species of Acentropelma Pocock, 1901 and Pseudoschizopelma Smith, 1995 detailed in this work: purple square $-A$. spinulosum, blue triangle $=$ P. macropus comb.rest., red circle $-A$. gutzkei. The locality mapped for $A$. spinulosum is that of Chicoyoito only as the other mentioned locality in F.O. Pickard-Cambridge (1897) could not be securely located (see text for discussion).

Рис. 27. Карта типовых местообитаний валидных видов Acentropelma Pocock, 1901 и Pseudoschizopelma Smith, 1995 по материалам данной работы: пурпурный прямоугольник - A. spinulosum, синий треугольник $=P$. macropus comb.rest., красный кружок - A. gutzkei. Местонахождение, обозначенное для A. spinulosum, относится к локусу Chicoyoito, поскольку другое упомянутое F.O. Pickard-Cambridge [1897] местонахождение не может быть надежно локализовано (см. обсуждение в тексте настоящей работы).

albeit the apex of the embolus is snapped on both palpal bulbs. Importantly, we also found appendages not belonging to either specimen in the original jar, which were therefore placed into a separate, labelled tube within the jar. Crucially, Smith [1995] made an error in considering these other "rogue limbs" (which include a palpal bulb and leg I tibia with apophysis - and possibly a metatarsus IV) to belong to the holotype male, and thus his illustrations and diagnosis of male morphological features of $P$. macropus are erroneous and do not correspond to a correct generic and species diagnosis, but instead are chimeric. Thus, this work provides the latest correct diagnosis of $P$. macropus since its original description by Ausserer [1875], consistent with his text and drawings.

Our comparison of the type specimens of P. macropus comb.rest. against several other specimens in NHMUK determined by other workers as $A$. sorkini revealed indistinguishable morphology between the male holotypes, and high similarity of some other specimens, therefore we propose $A$. sorkini syn.n. as a junior synonym of $P$. macropus.

The type locality of A. sorkini (St. Andres, Mexico) is vague, as many locations both within Mexico and in other Latin American countries have, or previously had a name including "Santo" or "San", which are anglicised as "Saint" then abbreviated "St.", else the Germanic "Sankt" to "Skt." or "St". However, we noticed the accession numbers of the type specimens of $P$. macropus comb.rest. and those later determined as $A$. sorkini were consecutive (see above), with all originating from the Keyserling collection (pers. obs.), suggesting they may have been collected around the same time and from similar locations. Given this, we believe Ciudad Serdán (formerly St./San Andres Chalchicomula) near to Pico de Orizaba is a plausible location for the "St. Andres" indicated on the anglicised/Germanic original la- bels and accession entries at NHMUK for those that later became A. sorkini. Ciudad Serdán, whilst presently is a comparatively small settlement, was once a major customs point on the route inland from Veracruz Port to Puebla city and Mexico City during the late nineteenth century when the specimens were collected. It lies within only around 20 kilometres distance from the type locality of P. macropus [Pico de Orizaba], so if indeed represents the location of collection of $A$. sorkini, then the close proximity of these two locations further supports the synonymy of $A$. sorkini with P. macropus.

Sexual dimorphism is well documented within theraphosid spiders, but although dimorphism through extreme differences in body size is recorded in some African species such as Augacephalus junodi (Simon, 1904) (e.g. Gallon, 2002), to date such extremes have not been recorded in any mesoamerican species - with a notable exception of that for $A$. sorkini [Smith, 1995]. However, when the size difference of the male holotype and female allotype of $A$. sorkini (where the described female is recorded as nearly double the body length of the holotype male) was reevaluated in our examination, the jar containing them was found to contain several specimens of two species from different genera. Smith [1995] mentions the holotype male and an allotype female but does not mention the presence of another six theraphosids: three females and three immature males, also present in the jar (giving eight total). The allotype female of A. sorkini described by Smith [1995] (as S. sorkini) was found to be an immature female of Brachypelma sp., possibly Brachypelma kahlenbergi Rudloff, 2008. However, at the time Smith was examining this specimen the latter species was undescribed. Another immature male and a further female are also not deemed conspecific to A. sorkini and are likely also juveniles of the same Brachypelma species. All 
specimens and appendages in the original jar were recurated, organised and placed into labelled tubes during this study, with the three non-conspecific specimens being moved to a separate jar from the holotype. The holotype male, two non-type females and two non-type immature males are all deemed conspecific. Dissection of genitalia from some specimens previously regarded as juveniles revealed two mature females with nearly identical spermathecal morphology (i.e. two receptacles emergent from a membranous base, see Fig. 26 ) to that of the allotype P. macropus (compare Fig. 19). Therefore these two others are here regarded as conspecific females to P. macropus (and to the holotype male of $A$. sorkini syn.n.). Similarly, two other juveniles (both apparently immature males) are considered as truly conspecific but with less certainty.

\section{Discussion}

One of the problems that can affect specimens in large, historical collections of dry pinned theraphosid spiders (and equally other arachnid groups) is that either whole or partial limbs can easily become removed from a specimen, then get dissociated within the drawer by rolling around each time it is removed from the cabinet. Vibrations of the drawer during its removal, or that of adjacent drawers, can cause breakage through fracture of the fragile membrane between limb segments. This can also be the case when a dried specimen is transferred to alcohol or simply recurated - when disarticulated limbs may be assumed to belong to that specimen and then associated with them, especially so if that nearby specimen is missing limbs. In various European dried theraphosid collections, small boxes or packets can sometimes be found in the corners of the drawers in recurated dry collections, which contain "unallocated" limbs that may or may not belong to whichever bodies remain in the drawer. This appears to have been the situation with the type specimens of $P$. macropus where "rogue limbs" were preserved alongside the actual limbs and bodies. Here, we believe the issue was further complicated by the inclusion of such unrelated limbs when the type specimens were transferred to alcohol.

The holotype male of $P$. macropus and the accompanying female that we here consider an allotype (and hence paratype) following Ausserer [1875] are both badly fragmented ex-dry/pinned specimens that required many hours of recuration and investigation prior to redescription. All the limbs from the female were dislocated from the body below the coxa while the left leg I and palp of the male were nearly complete but broken below the coxa, while other appendages were dislocated from the femur/trochanter junction. It was easy to allocate leg I and IV to the respective bodies of both, but more difficult with legs II and III as those were highly fragmented, with some pieces damaged, hence not allowing accurate length measurement allocation to any particular leg, nor to any particular specimen. Therefore measurements for legs II and III are not included in this work. Ausserer [1875] only includes leg mea- surements for male and female leg I and IV in his original description. While this was sometimes the standard for his time, we suggest his lack of details of legs II and III may indicate damage at a very early stage of preservation prior to their donation to the $\mathrm{BMNH} / /$ NHMUK. Though there is no indication as to when the specimens were transferred into alcohol, Doug Clark (the curator of Arachnida of that collection in the 1960s and early 1970s until his untimely death) may have been responsible, as other data labels in other specimen jars show he transferred much of the dried collection to alcohol (DS pers. obs.). Two other workers that examined P. macropus after F.O. Pickard-Cambridge were Berta Gerschman and Rita Schiapelli in 1968, and it is possible it may have been them who tried to reassemble these specimens, and even divided various limb fragments into individual vials.

Through careful recuration of the type specimens of $P$. macropus (i.e. a male and female), we determined that two "rogue limbs", namely a leg I and pedipalp, including the palpal bulb, were included in one of several vials associated with them in the same jar. It was these that we determine were erroneously illustrated in Smith [1995: 187, f. 1036-1040] as the palpal tibia, tibial spur and palpal bulb, each respectively being considered parts of the male holotype (probably confused from an earlier but non-concluded attempt to completely assemble it). To allocate correct limbs to the specimens, these "rogue limbs" were partly distinguished by difference in their pillosity — whereby the "correct" limbs of P. macropus lacked almost all of their setae due to damage and/or age. The comparative width was also considered as these 'rogue limbs' also had a larger diameter at the basal trochanter connections than expected from the body. We also appealed to details in the original description to support our position that the tibial I of the male holotype lacked any notable apophysis, and that the palpal bulb we allocated was correct [as drawn by Ausserer 1875]. After revalidation, all limbs that could be defined as coming from either of the two type specimens (holotype and allotype) were housed with their respective bodies in individual large tubes, while limb fragments that could not be clearly allocated to either were housed in smaller individual tubes. Finally, "rogue" limbs that did not seem associated with either were isolated and housed together separately, each being appropriately labelled.

Pocock [1901] defined the genus Acentropelma with focus on stout delicately plumose bristles on the "anterior trochanter and femur of the leg I" and "posterior trochanter of the palp" [Pocock, 1901: 554]. As a major focus here is instead on the morphology of the palpal bulb to define both Acentropelma and the restored genus Pseudoschizopelma, the distribution of the such modified setae on the respective trochanters and femorae is regarded herein as less reliable. Wider ongoing studies lead us to expect this aspect may vary intraspecifically in both genera. In this context, we 
recognise that the general form of the male bulb between these genera is very similar, which we hypothesize is indicative of their particularly close phylogenetic affinity. Yet, we suggest that the two genera can be distinguished on the finer aspects of the keelation, with our proposed division into separate genera supported by divergence in structures of the ventral tibia I in males. That said, in order to better ascertain the limits of possible intraspecific variation in these characters and others, it will of course be necessary for additional specimens of Acentropelma and Pseudoschizopelma to be collected and examined, and reevaluated against other plausible closely related genera such as Citharacanthus. An especially useful future step will be to characterise female specimens which are determined to correspond to A. spinulosum, and A. gutzkei, with due caution about matching specimens of different sexes together. However despite examining a large array of historical museum specimens during the course of this study, plus various additional specimens from the countries involved, we were unable to find any females that appeared to corresponded to those as yet undescribed.

Acknowledgements. We would like to thank Louis Sorkin, Lorenzo Prendini and the late Norman Platnick (AMNH), Jan Beccaloni (NHMUK) Christine Rollard and Elise-Anne Leguin (MNHN), Laura Liebensperger (MCZ), Jürgen Gruber and Christoph Hörweg (NHMV), Zoë Simmons, Amoret Spooner, James Hogan and Darren Mann (OUMNH) and Jason Dunlop and Anja Friederichs (ZMB) for allowing us access to their museum collections, arranging loans and allowing examination of material. We also thank OUMNH staff for allowing use of their auto-montage system (sponsored by the A. McCrae bequest). DS also thanks Alain Dubois (MNHN) for discussion on bionomial nomenclature. SJL also thanks Francisco Medina and Ignacio Vázquez (LAAHFC/UNAM) for access to collections in the Laboratorio de Acarología, and donation of some reference specimens. Two reviewers who supplied many useful comments and improving the layout are also thanked.

Compliance with ethical standards

Conflict of Interest: The authors declare that they have no conflict of interest.

Ethical approval: No ethical issues were raised during our research.

\section{References}

Ausserer A. 1871. Beiträge zur Kenntniss der Arachniden-Familie der Territelariae Thorell (Mygalidae Autor) // Verhandlungen der Zoologisch-Botanischen Gesellschaft in Wien. Bd.21. S.117-224.

Ausserer A. 1875. Zweiter Beitrag zur Kenntniss der ArachnidenFamilie der Territelariae Thorell (Mygalidae Autor) // Verhandlungen der Kaiserlich-Königlichen Zoologisch-Botanischen Gesellschaft in Wien. Bd.25. S.125-206.

Becker L. 1878. Diagnoses de quelques aranéides nouvelles du Mexique // Annales de la Société Entomologique de Belgique. Vol.21. P.77-80.

Bertani R. 2000. Male palpal bulbs and homologous features in Theraphosinae (Araneae, Theraphosidae) // Journal of Arachnology. Vol.28. No.1. P.29-42.

Bertani R. 2001. Revision, cladistic analysis, and zoogeography of Vitalius, Nhandu, and Proshapalopus; with notes on other
Theraphosine genera (Araneae, Theraphosidae) // Arquivos de Zoologia, São Paulo. Vol.36. P.265-356.

Gabriel R. 2016. Revised taxonomic placement of the species in the Central American genera Davus O. Pickard-Cambridge, 1892, Metriopelma Becker, 1878, and Schizopelma F. O. Pickard-Cambridge, 1897, with comments on species in related genera (Araneae: Theraphosidae) // Arachnology. Vol.17. No.2. P.61-92.

Galleti-Lima A.G., Guadanucci J.P.L. 2018. Morphology of setae on the coxae and trochanters of theraphosine spiders (Mygalomorphae: Theraphosidae) // Journal of Arachnology. Vol.46. No.2. P.214-225.

Galleti-Lima A.G., Guadanucci J.P.L. 2019. Comparative morphology of stridulating setae of Theraphosinae (Araneae, Theraphosidae) // Zoologischer Anzeiger. Vol.283. P.58-68.

Gallon R. C. 2002. Revision of the African genera Pterinochilus and Eucratoscelus (Araneae, Theraphosidae, Harpactirinae) with description of two new genera // Bulletin of the British Arachnological Society. Vol.12. Pt.5. P.201-232.

ICZN. 1999. International code of zoological nomenclature. Fourth edition. International Trust for Zoological Nomenclature, London. P.i-Xxix + 1-306.

Koch C.L. 1850. Übersicht des Arachnidensystems. Nürnberg: Verlag von Lotzbeck. Hf.5. S.1-77.

Pérez-Miles F., Lucas S.M., Da Silva P.I., Jr., Bertani R. 1996. Systematic revision and cladistic analysis of Theraphosinae (Araneae: Theraphosidae) // Mygalomorph. Vol.1. P.33-68.

Pérez-Miles F., Gabriel R., Sherwood D. 2019. Neischnocolus Petrunkevitch, 1925, senior synonym of Ami Perez-Miles, 2008 and Barropelma Chamberlin, 1940 (Araneae: Theraphosidae) // Arachnology. Vol.18. No.2. P.150-155.

Petrunkevitch A. 1925. Arachnida from Panama // Transactions of the Connecticut Academy of Arts and Science. Vol.27. P.51248.

Pickard-Cambridge O. 1892. Arachnida. Araneida // Godman F.D., Salvin O. (eds.). Biologia Centrali-Americana, Zoology. London. Vol.1, P.89-104.

Pickard-Cambridge F.O. 1897. Arachnida - Araneida and Opiliones // Godman F.D., Salvin O. (eds.). Biologia CentraliAmericana, Zoology. London. Vol.2. P.1-40.

Pocock R.I. 1901. Some new and old genera of South American Avicularidae // Annals and Magazine of Natural History Ser.7. Vol.7. No.8. P.540-555.

Raven R.J. 1985. The spider infraorder Mygalomorphae Araneae: Cladistics and systematics // Bulletin of the American Museum of Natural History. Vol.182. P.1-180.

Reichling S.B. 1997. A new species of Crypsidromus from Belize (Araneae, Mygalomorphae, Theraphosidae) // Journal of Arachnology. Vol.25. No.1. P.49-52.

Rudloff J.P. 1997. Revision der Gattung Holothele Karsch, 1879 nebst Aufstellung einer neuen Gattung Stichoplastoris gen. nov. (Araneae, Theraphosidae) und Wiedereinsetzung einiger weiterer Gattungen der Mygalomorphae // Arachnologische Magazin. Bd.5. H.2. S.1-19.

Schmidt G. 1993. Vogelspinnen: Vorkommen, Lebensweise, Haltung und Zucht, mit Bestimmungsschlüsseln für alle Gattungen. Vierte Auflage. Hannover: Landbuch - Verlag GmbH. $151 \mathrm{~S}$.

Schmidt G. 2003. Die Vogelspinnen. Neue Brehm-Bücherei, Hohenwarsleben. $383 \mathrm{~S}$.

Schmidt G. 2005. Die Gattung Davus O. P.-Cambridge, 1892 (Arachnida: Araneae: Theraphosidae: Theraphosinae) // Tarantulas of the World. Vol.104. P.7-18.

Simon E. 1888. Etudes arachnologiques. 21e Mémoire. XXIX. Descriptions d'espèces et de genres nouveaux de l'Amérique centrale et des Antilles // Annales de la Société entomologique de France. No.6. Vol.8. P.203-216.

Simon E. 1889. Voyage de M. E. Simon au Venezuela (décembre 1887 - avril 1888). 4e Mémoire. Arachnides // Annales de la Société entomologique de France. Vol.6. No.9. P.169-220.

Simon E. 1891. Liste des Aviculariides qui habitent le Mexique et l'Amérique centrale // Actes de la Société linnéenne de Bordeaux. Vol.44. P.327-339. 
Simon E. 1892. Histoire naturelle des araignées. Paris: Roret. Vol.1. Pt.1. P.1-256.

Simon E. 1903. Histoire naturelle des araignées. Paris: Roret. Vol.2. Pt.4. P.669-1080.

Simon E. 1904. Descriptions de quelques arachnides nouveaux faisant partie de la collection du Musée d'histoire naturelle de Genève // Revue Suisse de Zoologie. T.12. P.65-70.

Smith A.M. 1986. The tarantula: classification and identification guide. London: Fitzgerald Publ. $179 \mathrm{p}$

Smith A.M. 1987. The tarantula: classification and identification guide (second ed.). London: Fitzgerald Publ. 179 p.

Smith A.M. 1995. Tarantula spiders: tarantulas of the U.S.A. and Mexico. London: Fitzgerald Publ. $196 \mathrm{p}$

Thorell T. 1869. On European spiders. Part I. Review of the European genera of spiders, preceded by some observations on zoological nomenclature // Nova Acta Regiae Societatis Scientiarum Upsaliensis. Vol.3. No.7. P.1-108.

Turner S.P., Longhorn S.J., Hamilton C.A., Gabriel R., PérezMiles F., Vogler A.P. 2018. Re-evaluating conservation priorities of New World tarantulas (Araneae: Theraphosidae) in a molecular framework indicates non-monophily of the genera, Aphonopelma and Brachypelma // Systematics and Biodiversity. Vol.16. No.1. P.89-107.

Wagner R., von Rothkirsch C. 2001. The History of Coffee in Guatemala. Villegas Asociados S.A. (new edition). 224 p.

World Spider Catalog. 2020. World spider catalog, version 21.0 // Natural History Museum, Bern. Online at http://www.wsc. nmbe.ch.

Responsible editor S.L. Zonstein 